\title{
BENIOFF ZONES, ABSOLUTE MOTION AND INTERARC BASIN
}

\author{
Francis $\mathrm{T}$. Wu \\ Department of Geological Sciences and Environmental Studies, \\ State University of New York, Binghamton, New York, U.S.A. \\ (Received July 20, 1978; Revised October 9, 1978)
}

\begin{abstract}
While in the Honshu region, the Benioff zone exhibits a straight profile, dipping west at about $30^{\circ}$, the Mariana arc has a curved zone changing into a very steeply dipping zone at depth, and the Peru-Chilean arc has a very extended and gently dipping zone at $16^{\circ}$. These can be interpreted as three type-cases where, correspondingly, the trenchline is at rest with respect to the deeper mantle and the trenchline is moving in the dip direction with respect to the deeper mantle. Where the direction of relative motion has changed, we can then expect sharper bends as in the cases of Central Bonin and the Peru-Chilean arcs.

This interpretation is consistent with the concept of the decoupling of plate motion across the asthenosphere and enables us to use the Benioff Zone to decipher the recent history of absolute plate motion.

The steepening of the Marianas Zone is closely related to the westward motion of the Philippine Sea Plate. The separation of the plates due to anchoring of the trenchline, after the subducted lithosphere reaches the mesosphere, and the continued westward motion of the Philippine Sea Plate is probably responsible for the formation of the back-arc basin and the lack of large shallow thrust-type earthquakes there. This could be one of the several mechanisms for the formation of the back-arc basin.
\end{abstract}

\section{Introduction}

Relative motions of tectonic plates have been studied in great detail (LEPrCHON, 1968; Morgan, 1968; Minster et al., 1974; among others). Recently, attention has been turned to the "absolute" motion of plates (MORGan, 1972; WiLson, 1973; Mrnster et al., 1974; and others). Strictly speaking, "absolute" is with respect to the Earth's center. But since the upper mantle below the asthenosphere, the mesosphere, is often considered to be decoupled from the plate motion, and the motion of the mesosphere is probably of the order 1-2 cm/year (MOLNAR and FRANCHETEAU, 1975), slower than most of the plate velocities we are interested in, we may regard the mesosphere as stationary. Depending on the absolute motions of plates in a subduction regime, the subducted lithosphere may have to move through the asthenosphere. The resistant force exerted by the asthenosphere can conceivably modify the shape of the slab. Also, after the slab has been inserted into the mesosphere, the motion of the trenchline may be restricted; this restriction in motion of the trenchline may create tension on the upper plate side, if the upper plate is moving away from the trenchline.

Seismic data, in general, are of ephemeral nature in comparison to the time needed to create major geological expressions. Thus focal mechanism solution is reflecting the stress conditions and the orientation of the fault planes prevalent at the time of the earthquake and the present shallow seismicity may only have a vague memory of what has gone on millions of years before. The Benioff zone, interpreted as a subduction zone, bears 
information regarding the motions of the plates associated with that boundary for the duration of its activity; when the length of the subduction is $L$ and the velocity of subduction is $V$ then the duration is $L / V$. In other words, under our assumptions, the varying slope of a Benioff zone as a function of depth coupled with velocity of subduction can be translated into time history of the absolute motions of the plates involved. Because most of the Benioff zones are continuous and the obvious breaks in some of them are short, the time resolution of our interpretation is finer than that based on discrete volcanic islands although only the recent 10 million years or so history can be studied this way.

Aspects of the relation of the shape of Benioff zone to the motion of plates (or more precisely the trenchlines) have been discussed by McKenzIE and Morgan (1969), LuYeNDIK (1970), Tullis (1972, 1976), Wu (1971, 1972), KARIG (1971b), Wilson (1973), JACOBy (1973), and Tovish and Schubert (1978) among others. In this paper, we shall attempt to systematically examine the well-defined Benioff zones and explain the inclinations and the changes in inclination as a function of depth in terms of absolute motion and change in absolute motion in the past. We shall include in these discussions considerations regarding the generation of down-dip stresses (IsAcks and BARAZANGI, 1977; HASEgawA et al., 1978) as well as the magnitude and frequency of earthquakes.

A problem closely related to the subduction zone, namely the formation of interarc basin has received much attention (KARIG, 1971a, b; ToKsoz and BIRD, 1977; UyedA and KANAMORI, 1978; PoemLs, 1978; and others). We shall briefly discuss the kinematics in terms of absolute motions of trenchlines and separation of plates.

\section{Interpretation of Different Configurations of Benioff Zones}

Along each island arc the configuration of Benioff zone varies, not only in the downdip direction but also laterally. The lateral variations in some cases can be understood in terms of the variations of the absolute velocities of the plates involved. In this section we shall be concerned with the depth profiles only. But in our discussion of the actual arcs later, the variations of shapes along the arcs shall be taken into consideration.

IsACKs and MolNaR (1971) and IsACKs and BARAZANGi (1977) have summarized the general shapes of the Benioff zones perpendicular to the trench as well as the down-dip stresses which has partly been updated by the works of HASEGAWA et al. (1978). Figure 1 is a reproduction of Isacks and Molnar's results.

Of the well-developed Benioff zones, we can distinguish three cases: (1) very straight and moderately dipping zone (example: Honshu), (2) steeply dipping zone (example: the lower portions of Marianas and Peru), (3) curved and very shallow dipping zones (example: the upper portions of Peru and Chile zones). Some of the zones can be recognized as a combination of 2 and 3 (example: Peru and Chile zones, deep parts included; New Hebrides).

Although ISACks and MolnaR (1971) believe that the irregularities in the Benioff profiles represent relative motion of the upper and the lower part of the slabs, they called the non-straightness of the profiles "contortions", and felt that both the contortion and the distribution of the down-dip stresses are not amenable to simple explanations. McKenzie and Morgan (1969) however, in an attempt to match the slope of the Ryukyu Benioff zone to the average slope of the Bonin Benioff zone, postulated that the matching can be done by moving the Bonin trench eastward for about $200 \mathrm{~km}$, implying that the steeper profile of the Bonin Benioff zone was a result of the westward motion of Bonin 

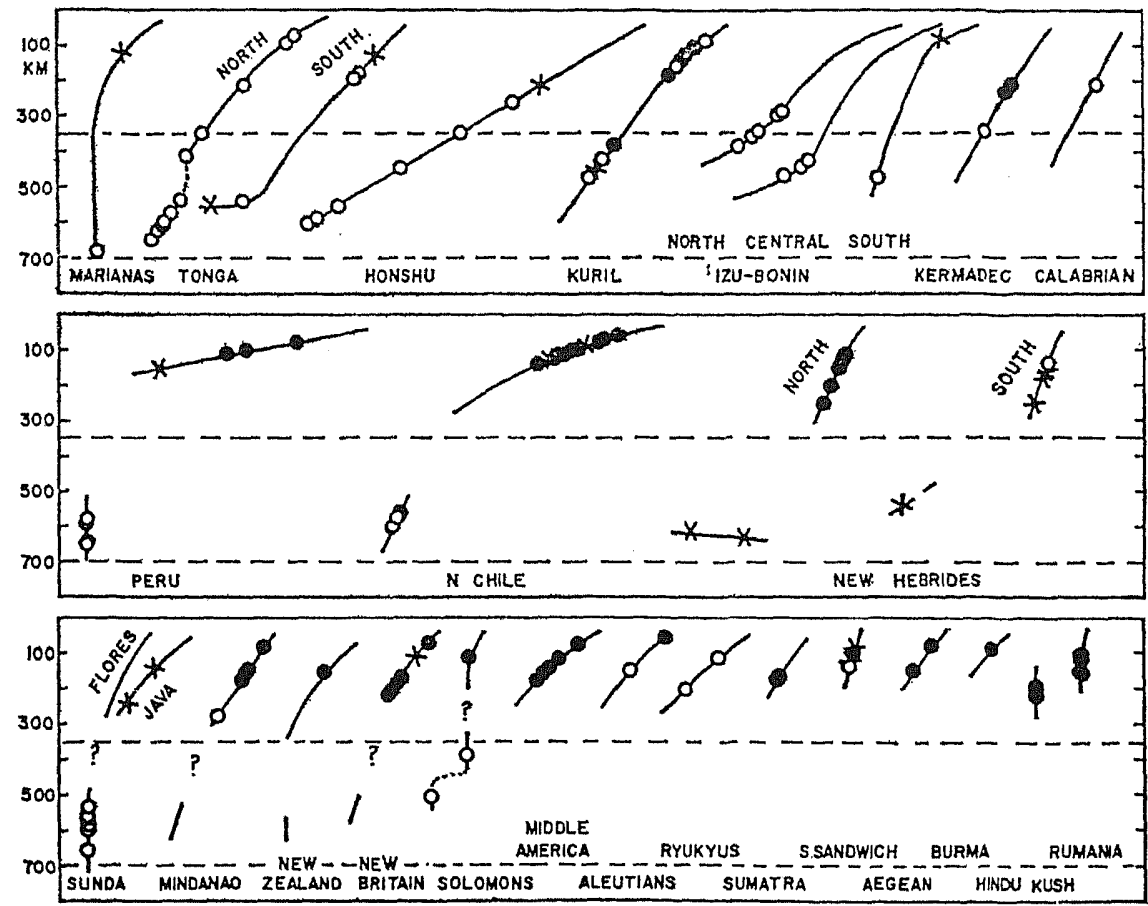

Fig. 1. Global summary of the distribution of down-dip stresses in inclined seismic zones. The stress axis that is approximately parallel to the dip of the zone is represented by an unfilled (open) circle for the compressional or P-axis and a filled (solid) circle for the tensional or T-axis; an $\mathrm{X}$ indicates that neither the $\mathrm{P}$ - nor the $\mathrm{T}$-axis is approximately parallel to the dip. For each region the line represents the seismic zone in a vertical section aligned perpendicular to the strike of the zone. The lines show approximately the dips and lengths of the zones and gaps in the seismic activity as a function of depth. (After IsACKs and Molnar, 1971)

trench. KarIG (1971b) concluded that the slope of the upper portions of several Benioff zones are influenced heavily by interarc spreading. Wu $(1971,1972)$ applied the concept of absolute motion of plates and explained the change of dip of Benioff zone along the Izu-Bonin-Marianas arc as a result of the clockwise rotation of Philippine Sea Plate. He also described the shallow dipping of the Benioff zone under South America as a result of overriding of the Nazca plate by South America. Tullis (1972) thought that the deeper part of the Benioff zone may have an anchoring effect. Wilson $(1973,1974)$ had similar conclusions as cited above. Since the discovery of the double seismic zone (HASEgawA et al., 1976, 1978; IsACKs and BARAZANGI, 1977) the down-dip stresses in some cases have been understood much better.

In this section, we shall cast the ideas expressed in my earlier works cited above in a more systematic way and extend the arguments further toward a more complete presentation.

For two plates in contact, the absolute velocities $V_{1}$ and $V_{2}$ (let us consider only the components perpendicular to the arc) determine whether initially a subduction zone would form. The "truth table" is shown in Fig. 2. The conditions (1), (5), (6), and (7) represent situations where subduction can occur and (2), (3), (4), and (8) are cases where 


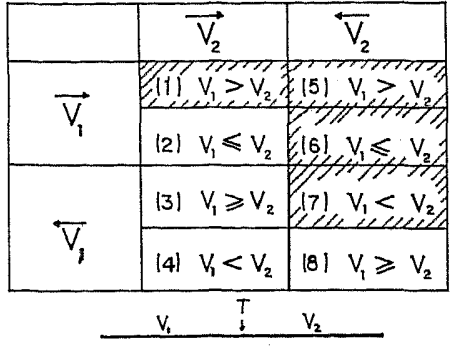

Fig. 2. "Truth table." The arrows over $V_{1}$ in the table indicate the direction of the velocities $V_{1}$ of the plates as shown schematically below the table. Shaded areas indicate the subduction will occur under that condition.

spreading will occur. If conditions (1) or (7) persists after the initiation of subduction, at first the trenchline will attempt to follow the upper plate, but as the plate enters deeper into the asthenosphere and then the mesosphere, the motion of the trenchline will be greatly hindered due to the resistance exerted on the subducted slab by the asthenosphere and the mesosphere. Under these conditions, there will be a lack of compression and shallow seismicity near the plate boundary; backarc spreading can take place, and the Benioff zone is likely to be steep. If conditions (5) and (6) persist, on the other hand, the trenchline will be forced to migrate against the direction of subduction due to the overriding of the subducting plate by the upper plate; in this instance, the compression is high, therefore shallow, large earthquakes can take place. In cases (1), (5), (6), and (7), if one of the velocities becomes zero then the trenchline will be stationary.

Thus, based on the motion of the trenchline, we can distinguish three cases:

I. When the trenchline is stationary. FRANK's (1968) attempt to explain the dip of Benioff zone assumed a rigid shell, then, on a sphere, the dip of the Benioff zone will be equal to two times the radius of the surface trace of the island arc in degrees. In vertical profile, such a zone will be a straight line. As Tovish and Schubert (1978) concluded however, the correlation of the dip angle with the radius of curvature is too poor for Frank's simple geometrical relation to be significant in determining the dip angle. JACOBY (1973) demonstrated by a simple model experiment that gravity sinking of a non-rigid slab also keeps a straight profile after it enters into the underlying liquid.

Because of the expected high viscosity of the mesosphere, the subduction zone can be expected to incline at the slope at which it emerges from under the asthenosphere to enter the mesosphere. Once this angle is established, the subduction will persist at that angle, unless there is substantial convection in the mantle, or if the subducted lithosphere has to move through the asthenosphere and/or the mesosphere.

Such profile exists-in its full form to the depth of $700 \mathrm{~km}$ only in one arc, i.e. Honshu (Fig. 1). Disregarding profiles that only extend to intermediate depths, whereby a good definition of the subducted zone is not possible, then we can determine one area on the globe where the relative velocity between the trenchline and the mesosphere is near zero. The time interval when this conclusion is applicable is from about 15 mybp to present.

IsACKS and MOLNAR (1971) show that the focal mechanisms for earthquakes indicate down-dip compressive stresses for earthquakes along the whole slab, although recent works by HASEGAWA et al. (1978) show a well-defined double-zone under northeastern Japan down to a depth of about $150 \mathrm{~km}$ and the mechanisms along the top zone indicate thrust faulting or down-dip compression while the bottom zone indicates down-dip tension. These results are consistent with the unbending of the Benioff zone going into the astheno- 


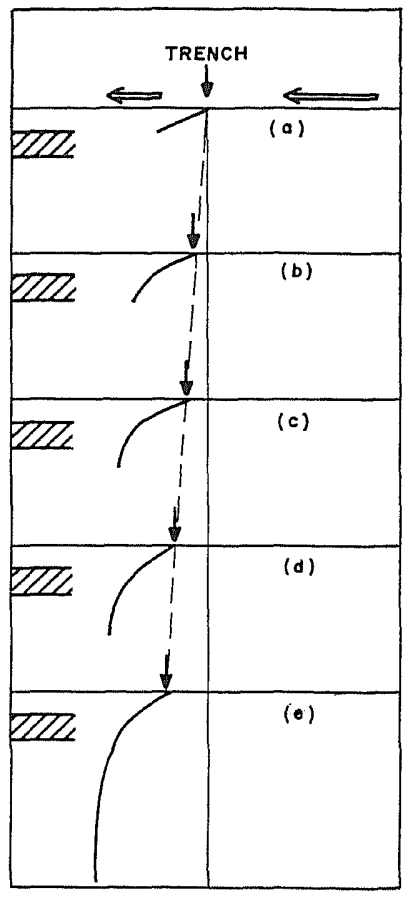

Fig. 3. The configuration of Benioff zone for a case where the upper plate is moving away from the trench line. See text for details. Hatched zone represents asthenosphere.

sphere (Isacks and Barazangi, 1977; Engdahl and Scholz, 1978; Hasegawa et al., 1978).

II. Where the trenchline is migrating in the direction of subduction. In Fig. 3, we have shown schematically the sequence of events that could lead to a configuration such as that under the Marianas (Fig. 1). As soon as the lithosphere dips into the asthenosphere, its advance through the asthenosphere will be resisted much as a vane moving through a viscous liquid would be resisted. As a consequence, the lithosphere will be bent further. The resistance will increase as a function of viscosity of the asthenosphere and the velocity at which the trenchline migrates.

If the bending force is such that when the tip of the subducted lithosphere is inclined at $90^{\circ}$ or less from the horizontal, then it will enter the mesosphere; if the dip is greater than $90^{\circ}$, i.e., the lithosphere overturns, then the plate may be broken off and left behind.

Upon entering the mesosphere where the viscosity is expected to be high, it is likely that the subducted lithosphere acts as an anchor for the trenchline, although the anchoring could not be perfect because of the finite viscosity. If the upper plate keeps on moving after the subducted plate reaches the mesosphere, then near the plate boundary there will be a general lack of compression. We may observe two consequences. First, tension may occur behind the arc and the formation of back-arc basin may ensue. Secondly, due to the lack of compression, large shallow-thrust earthquakes may not occur.

For this case, the stress distribution will be quite different from that of the last case (with a stationary trenchline). Using the Marianas as an example (see next section), from 0 to $150 \mathrm{~km}$, the curvature of the Benioff zone increases and we expect the down-dip tension type of mechanisms to be associated with earthquakes near the top of the lithosphere, and down-dip tension for events near the bottom of the lithosphere. 


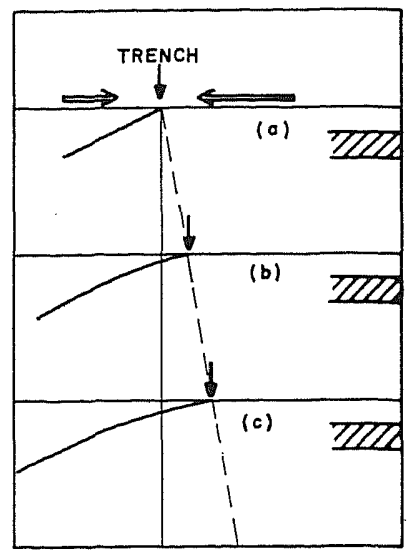

Fig. 4. The configuration of Benioff zone for a case where the upper plate is advancing over the trench. See text for detail.
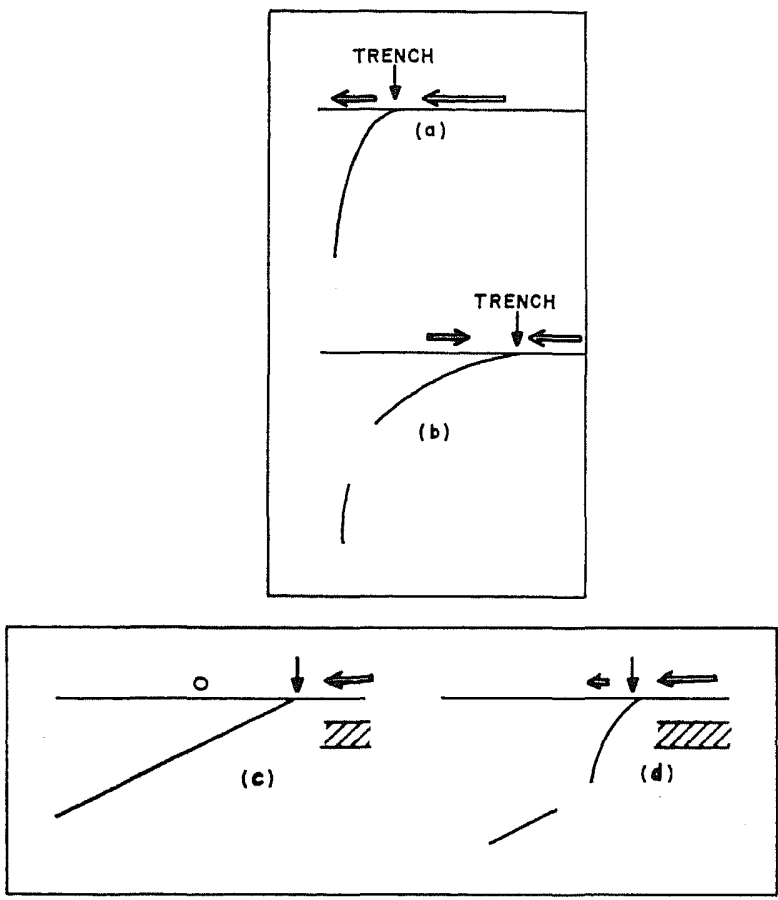

Fig. 5. The configurations of Benioff zone for cases where the absolute motions of plates changed during the course of subduction: $a$ and $b$, from upper plate moving away from the trench to moving over the trench; $c$ and $d$, from stationary upper plate to the upper plate moving away from the trench.

III. Where the trenchline is advancing against the direction of subduction. Assuming that the plate is subducting at an initial angle of $45^{\circ}$ (Fig. 4(a)); as the trenchline is advancing in the direction opposite to that of subduction, a movement of the point at which the lithosphere enters will be applied at the point where the asthenosphere will occur, thus 
the dip of the subduction zone will decrease. The viscous asthenosphere will resist the rotation of the subducted lithosphere and as the subduction continues and the lithosphere gets farther from the subduction point, the dip of the subduction will not be influenced further by the motion of the upper plate. Figure $4(\mathrm{~b})$ and (c) show schematically the sequence of possible events in such a case.

The seismicity in this case will involve very large, shallow thrust type of earthquakes.

$I V$. Where in the past history of the formation of the subduction zone has the sense of motion changed. If the initial subduction is in any one of the three categories discussed above and changed later to any other category, then a discontinuity in curvature or a break may exist in the Benioff zone (Fig. 5(a) and (b)). Such discontinuity is seen in Chile, Peru, New Hebrides, South Tonga, etc. (see Fig. 1). While for Peru, Chile and New Hebrides there are actually discontinuities in Benioff zones, for Tonga the profile is without gaps.

\section{Discussion of Examples}

In the last section, we have discussed the possible consequences of absolute plate motions upon the shapes of the Benioff zones. In this section, we shall explain in some detail several examples for illustration. In the process, we will be able to provide another basis for determination of the sense of absolute motion (in addition to that provided by the "hot spot" theory).

\subsection{Izu-Bonin-Marianas-Yap-Palau}

The clearest example of case II is the eastern margin of the Philippine Sea Plate.

The Philippine Sea Plate itself is relatively simple; it has a typical oceanic crust in most parts (Murauchi et al., 1968) and probably thin lithosphere of about $50 \mathrm{~km}$ (KANAMORI and ABE, 1968). There are some older structures in several parts of the Philippine Sea, such as Oki-Daito Ridge, the Central Philippine Basin Fault (Hess, 1946) and PalauKyushu Ridge that are not yet fully understood. Some of these structures apparently have not been active since mid-Miocene (Mizuno et al., 1978); therefore, for our purpose, they can be viewed as part of the inert plate. The formation of the Young Mariana Trough and the variations in subduction geometry of the eastern boundary are the problems that we shall attempt to address by using the concept described in the previous section (case II).

The seismicity along the eastern boundary of the Philippine Sea Plate, namely along the Izu-Bonin-Marianas-Yap-Palau arcs, has been studied by Katsumata and Sykes (1969) and more recently by IsACKs and BARAzANGI (1977). In the cross section (Fig. 6) based on Katsumata and Sykes (1969) the slope of the Benioff zone below $100 \mathrm{~km}$ steepens successively southward. The lengths of the Benioff zone under Izu-Bonin and the Marianas remain about $800 \mathrm{~km}$, thus the depth of the zone increases toward the Marianas. The seismicity under the Volcano Islands (near $25^{\circ} \mathrm{N}$ ) and the southern part of the long arc chain is low; although as pointed out by ISACKS and BARAZANGI (1977), the foci under the Volcano Islands do reach $500 \mathrm{~km}$ depth, the foci definitely shoal under the southern Marianas and only shallow $(0-30 \mathrm{~km})$ foci are found under the Yap and Palau. As shown in Fig. 7, adapted from IsAcks and BARAZANGI (1977), the $500 \mathrm{~km}$ foci lie directly under the $100 \mathrm{~km}$ foci near the Volcano Islands. The Benioff zone implied by Fig. 7 would have an increasingly steep profile starting from Izu Island going southward toward the Marianas, where the zone below $200 \mathrm{~km}$ becomes vertical; under the Volcano Islands and the northern Marianas the zone has overturned. 

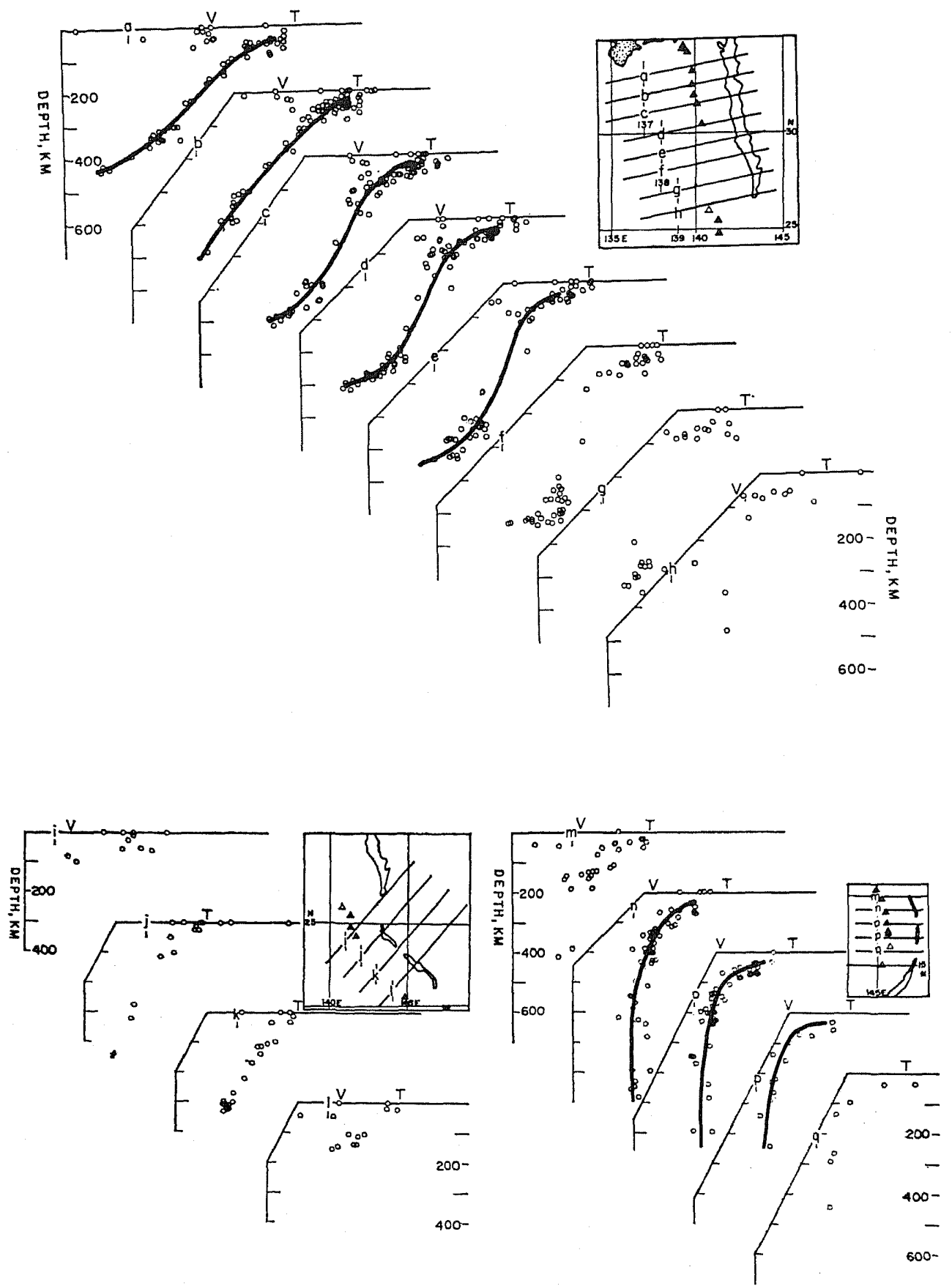

Fig. 6. Series of closely spaced vertical sections perpendicular to Izu-Bonin-Marianas trench showing changes in configuration and apparent thickness of deep focal zone. Orientation of sections shown in upper right corner, $\mathrm{V}$ denotes volcano and $\mathrm{T}$ denotes trench. (After Katsumata and SYKES, 1969) 


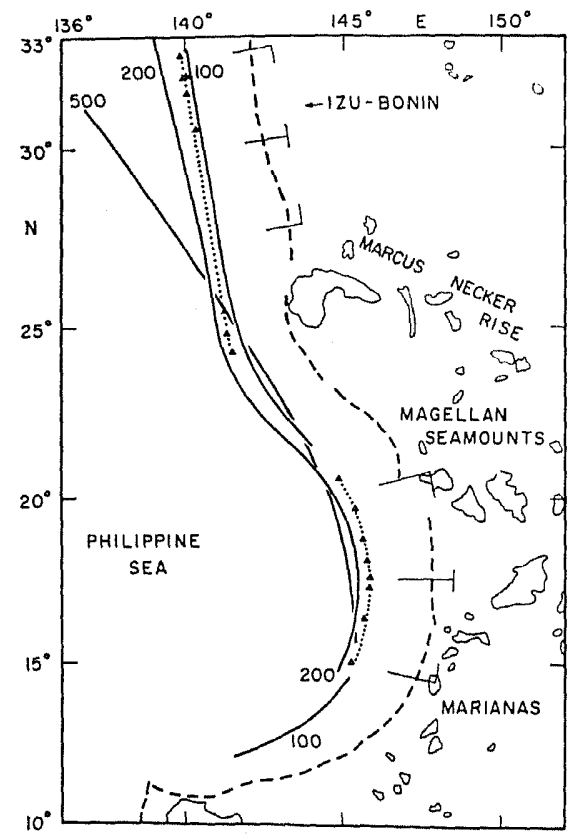

Fig. 7. The Benioff zone contours under Izu-Bonin and Marianas showing the overturn of Benioff zone near $25^{\circ} \mathrm{N}$ and $15^{\circ} \mathrm{N}$. (After IsACKs and BARAZANGI, 1977)

In explaining the geometry of the eastern boundary of the Philippine Sea Plate, it is noted first that the Philippine Sea Plate itself is rotating clockwise (with respect to the lower mantle) around a pole close to the junction of the Izu-Bonin arc with the Honshu $\operatorname{arc}(\mathrm{Wu}, 1971$ ). As a result, the upper plate moves west at an increasing rate from IzuBonin toward the Marianas, Yap and Palau. In the north, the velocity of the Pacific plate is much higher than that of the Philippine Sea plate so the subduction takes place more or less normally. To the extreme south, across the Palau arc, the velocity of the Philippine Sea Plate almost matches that of the Pacific plate and little or no subduction is taking place there. Perhaps south of Palau the velocities match exactly and no hint of subduction is detected.

In between, the slope of the subduction zone increases southward as a consequence of the more rapid westward migration of the trenchline. Initially, the trenchline would follow the upper plate; as the subduction zone reaches beyond the mesophere, however it provides at least a partial anchor for the trenchline. The continuous pulling away of the Philippine Sea then causes tension to occur west of the trenchline, thus the formation of the southward widening Mariana Trough. According to this scheme, the back-arc basin ought to widen starting from the junction of Honshu and Izu. As VoGT et al. (1976) have suggested however, the approach of the Marcus-Necker ridge has probably created the bend in the Izu-Bonin-Marianas chain. In our concept, this is equivalent to speeding up the westward migration of the trenchline at the bend, and thereby creating an overturn of the subduction zone and perhaps closing the back-arc basin there.

The seismicity in the Marianas is quite low and the lack of large shallow thrust-type earthquakes is especially noticeable along the whole eastern boundary of the Philippine Sea Plate. Such lack can be expected from the presence of a tensile regime behind the arc due to plate separation. 


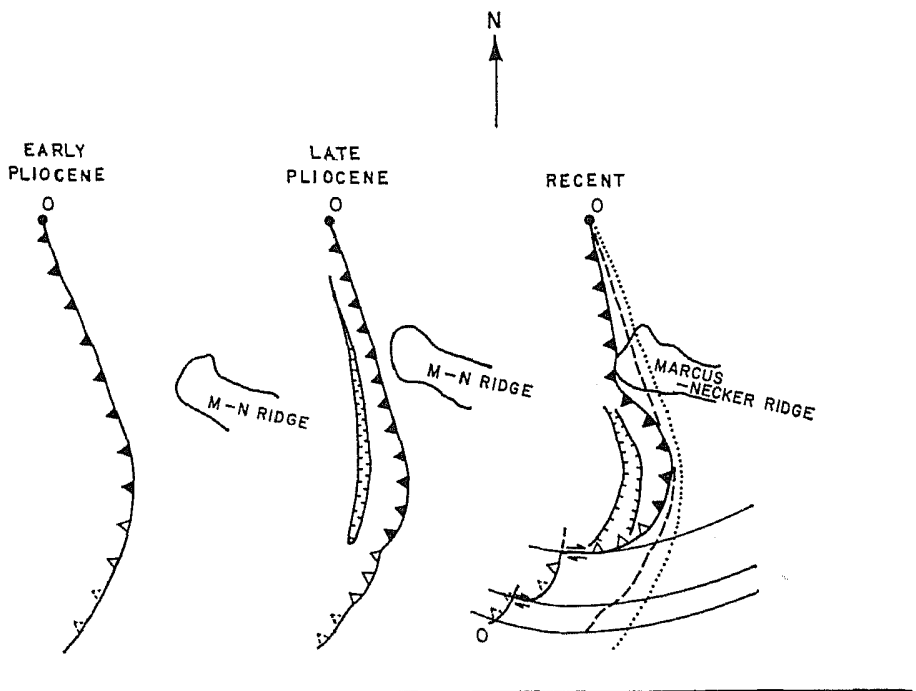

Fig. 8. Reconstruction of the tectonic history of the Marianas.

Because of the low seismicity, very few focal mechanism solutions are available by using world-wide data. There is the possibility that the double zone can be detected in the Marianas by using local high sensitivity stations. From the increase of the curvature of the Marianas subduction zone, the top down-dip tension and bottom down-dip compression may persist to greater depth than under the Honshu and the "unbending" should commence at a depth of about $150-250 \mathrm{~km}$.

We shall now attempt to reconstruct the history of the eastern boundary of the Philippine Sea Plate since early Pliocene (KARIG, 1971b). The time that corresponds to this age is about 10 mybp, which is consistent with the length of the Benioff zone divided by the absolution velocity ( $L=800 \mathrm{~km}, V=9 \mathrm{~cm} /$ year, $L / V \sim 9 \times 10^{6}$ years). This perhaps represents the latest "pulse" of subduction activity along this boundary (KARIG, 1971b).

The reconstruction is shown schematically in Fig. 8. Beginning from early Pliocene, the subduction zone we see now started to form. The initial boundary could have been a broad arc. As the subduction proceeded because of the differential resistance to motion between sections, the arc began to tear along small circles around the rotation pole. This tear becomes more pronounced as the subduction zone reached the mesosphere. In late Pliocene, an interarc basin opened along the lithosphere weakened by thermal activity associated with the subduction because of the tension created by the pulling away of the Philippine Sea Plate and the anchoring of the trenchline. Then the Marcus-Necker Ridge that came in contact with the Philippine Sea Plate, started to push the subduction boundary in front of the ridge westward, closing partially the interarc basin north of it and overturning the Benioff zone directly in front of it. From then on, the basin behind the Marianas arc continued to open and the tear and bending of arcs continued until today.

\subsection{Peru and Chile}

Seismicity and focal mechanisms of the western margin of South America have been 
discussed by Isacks (1970), Isacks and Molnar (1971), Stauder (1973) and Isacks and BARAZANGI (1977).

The main feature in both regions are a very shallow-dipping upper Benioff zone and a very steep-dipping lower Benioff zone. The two zones are apparently broken as shown by seismicity, but based on wave propagation studies, opinions differ. IsAcks and BARAZANGI (1973) believe that high frequency arrivals from deep earthquakes at the stations indicate a continuous slab; SNoke et al. (1973) interpreted the high frequency arrivals as phases reflected at the top interface between the slab and the mantle, thereby negating the necessity of assuming a continuous slab from $650 \mathrm{~km}$ up to the trench. As far as our present discussion is concerned, the question of continuity of the slab is not so important as the change in dip between the shallow and the deep parts.

There are discernible differences among the Benioff profiles under Peru, northern Chile, central Chile and southern Chile as shown by Barazangr and Isacks (1976) and IsACKS and BARAZANGI (1977). Barazangi and Isacks' profiles are adapted and shown in Fig. 9. While the lengths of the observable upper Benioff zones in these areas are about the same $(\sim 730 \mathrm{~km})$, the northern and southern Chilean profiles (section C-C) appear to be concave downward, but the Peruvian and central Chilean profiles are concave upward between 100 and $300 \mathrm{~km}$ inland from the trench, then became flat further inland and finally became concave downward (sections B-B and D-D). The common feature for all these profiles is the small dip angle of the Benioff zones.

Section C-C can be interpreted as resulting from a westward-advancing South America over the Nazca plate based on the description in case III (Fig. 4). The length of the subduction divided by the average relative motion velocity gives an age of about 6.5 my. Then we can estimate the distance of the trench has migrated westward by multiplying the absolute velocity of South America moving west: $23 \mathrm{~mm} /$ year $\times 6.5 \mathrm{my} \cong 150 \mathrm{~km}$.

The Peruvian and the central Chilean sections can be viewed as anomalous in that they are perturbed because of the subduction of aseismic ridges: the Nazca Ridge for Peru and Juan Fernandez Ridge in the case of central Chile (see for example VoGt et al., 1976). The point at which the Nazca Plate contacts the South American Plate moved south, because the ridge is oblique to the direction of subduction. If the dip angle of the Benioff zone is proportional to the density of the subducted lithosphere, then the less dense aseismic ridge would form the low angle Benioff zone. The absence of a trench where the aseismic ridges come to the subduction boundary, whence not very much sediments are carried down to depth, will be responsible for the lack of recent volcanism over the subducted ridges.

The deeper part of the subduction zones have apparently very steep dips. It could mean that before 7 mybp, the sense of the absolute motions of the South American plate might have been different, i.e., it could have been moving east. The rather drastic change in the dip between the deeper Benioff zone and the shallower Benioff zone represents a change in the nature of the plate motions there.

\subsection{Tonga-Kermadec}

Along the Tonga-Kermadec zone, the Benioff zone, below about $100 \mathrm{~km}$, steepens southward from about $45^{\circ}$ in northern and southern Tonga and $60^{\circ}$ in Kermadec (Fig. I). According to our previous discussion, we would expect the trenchline to have moved westward with respect to the lower mantle in the southern part of this chain. One possible cause for this behavior is the slowing down of subduction in New Zealand due to the buoy- 


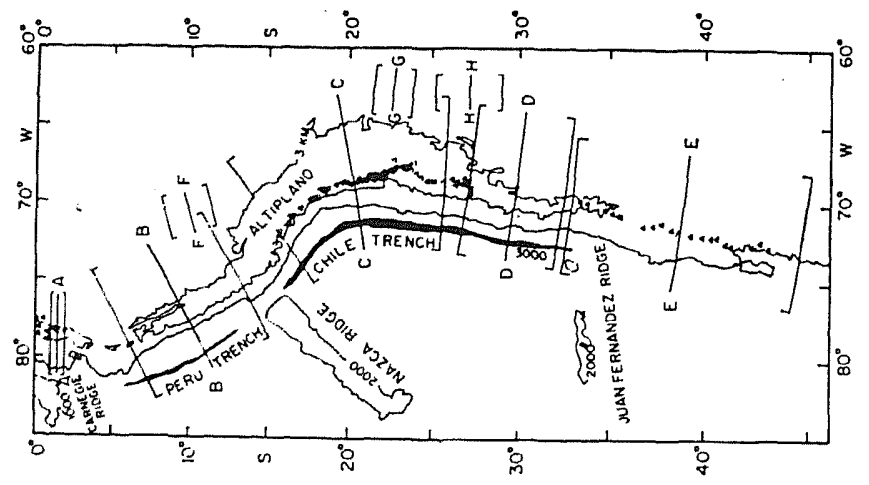

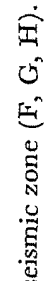
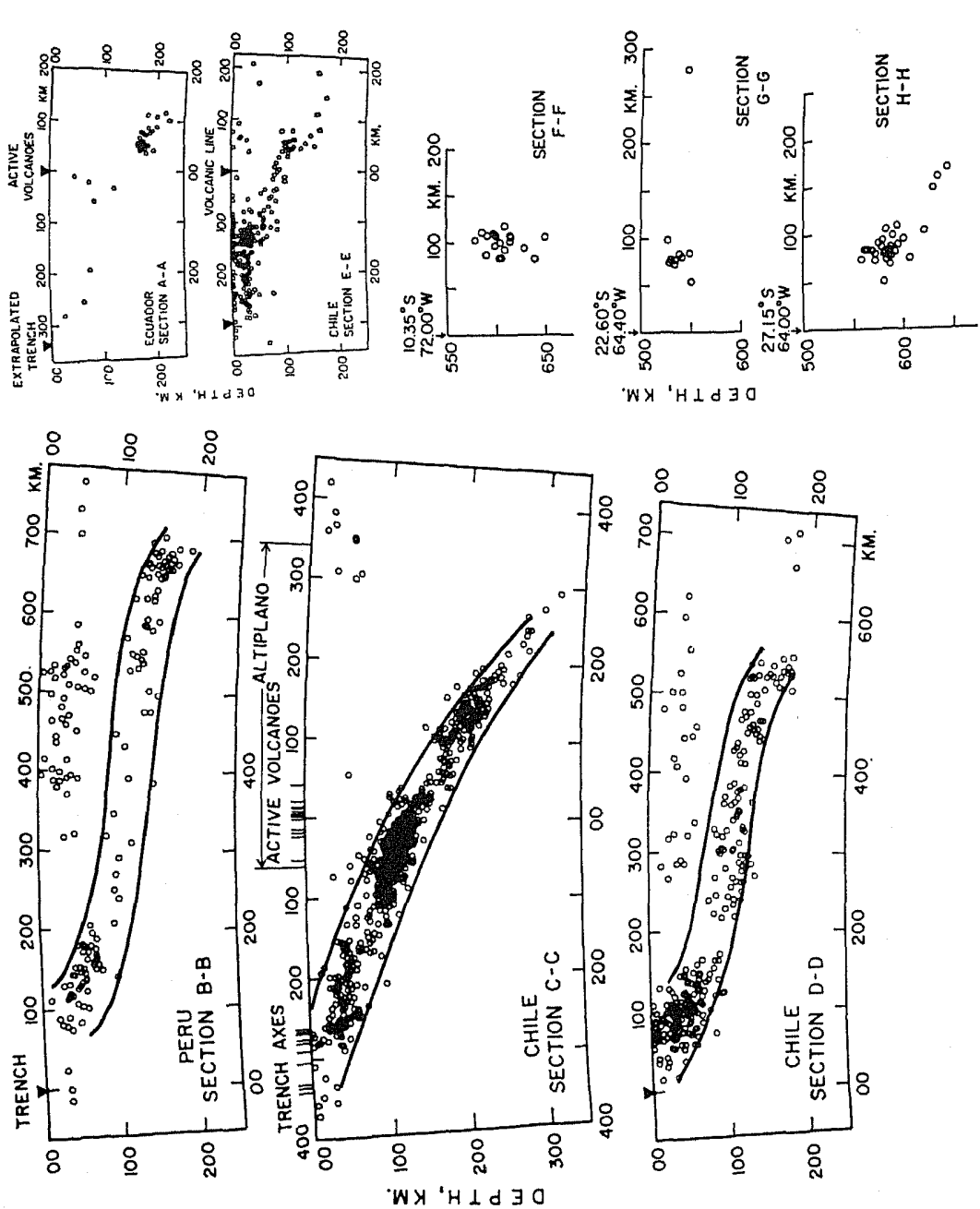

年 
ancy of the Chatham rise and the New Zealand Plateau and the push they exert on the Indian plate. The relative short subduction zone under New Zealand is fairly steep $\left(65^{\circ}\right)$.

Behind Tonga, we have one of the interarc basins that are considered to be active (KARIG, 1971). In contrast to the Marianas, here the map view of the trough is closely related to the configuration of the Benioff zone underneath where the subduction has a gentle dip, the interarc basin is wide, and vice versa.

\section{Back-Arc Basins}

Interarc basins are found behind some arcs (Marianas, Tonga, etc.) but not others (Aleutians, New Hebrides, Indonesia, etc.). They seem to form an integral part of some of the arc systems and are therefore important features to be understood in order to further our understanding of the global tectonics. UYEDA (1977) has summarized the possible mechanisms that operate to create the basins namely, ridge subduction, ocean basin entrapment, backarc opening ("Karig's process") and leaky transform faulting. It is difficult to envisage ridge subduction to be genetically related to the formation of interarc basin. Since the ridge represents a weakness, the subducted ridge may create a break in the subduction zone, but whether this could in turn cause a basin to open above this break is to be considered. The Gulf of California example can conceivably be explained by the northward propagation of the East Pacific Ridge rather than the eastward migration of it. The entrapment scheme will leave a basin behind the arc not genetically related to it. Back-arc opening and leaky transform faulting are still being actively studied (Toksöz and BIRD, 1977; UYEDA, 1977).

In a previous paper (Wv, 1972) and in the previous discussion in this paper, we have proposed another mechanism namely, the creation of interarc basin due to the tension resulting from plate separation and possibly the closing of parts of the basin due to the compression arisen from the forced migration of sections of the trench toward the basin. We have discussed the possible mode of formation of the Mariana Trough and closure of the Izu-Bonin Trough as well as the southern part of the Ian-Haure Trough based on these reasonings. The plate-separation tension can explain the lack of large earthquakes in the Marianas (WU, 1972).

The northern part of the Lau-Havre Basin is more complicated. WeISSEL (1977) interprets the magnetic profiles based on the back-arc opening model, but the patterns are by no means clear. SCLATER et al. (1972) had earlier interpreted similar data quite differently. Poefls (1978), using Sclater's model, hypothesized an opening of the Lau Basin through shear along the left-lateral fault separating the Fiji Plateau from the south Fiji Basin (see also Wu, 1972). It is a question however, whether the lithosphere is rigid enough to transmit this stress for over $1,000 \mathrm{~km}$. It is possible that the Pacific Plate is connected or coupled strongly through large-scale asperities on the plate boundary to the south Fiji Basin and the lithosphere behind the Tonga arc is torn apart at its weakest points, namely where the magma rises from the subduction zone. In fact, morphologically Lau Ridge and the Fiji Islands are continuous and the Fiji Islands have apparently undergone counter-clockwise rotation in the recent past (GREEN and CULLEN, 1973), indicating the nature of the deformation of the Fiji Plateau.

Another factor worth considering is that the descending slabs, especially those descending at higher rates are denser than the surrounding mantle material due to the lower temperature in the slabs (MInear and Torsöz, 1970). SEgAWA and Tomoda (1976) 
confirmed Minear and Toksoz's result by demonstrating that if the known crustal density structures near northeast Honshu and across the Shikoku Basin, Izu-Bonin Ridge and Izu-Bonin Trench are taken into account, then a heavier slab with $\Delta \rho \sim 0.05 \mathrm{~g} / \mathrm{cm}^{3}$ is needed to fit the free-air anomally data. In the presence of this denser slab, isostatic equilibrium is maintained if the material over the slab is less dense than the surrounding or if the column, i.e., with a depression over the slab, or a combination of both. According to the Airy principle (Heiskanen, 1938), the elevation of anomalous column is related to the excess density in the slab $\rho_{\mathrm{s}}$, the vertical thickness of the slab $\Delta R$ and the density of the average mantle $\rho_{0}$ by

$$
h=\frac{\Delta R\left(\rho_{\mathrm{s}}-\rho_{0}\right)}{\rho_{\mathrm{s}}} .
$$

If $\Delta R=100 \mathrm{~km}, \rho_{\mathrm{s}}-\rho_{0}=0.05 \mathrm{~g} / \mathrm{cm}^{3}, \rho_{\mathrm{s}}=3.25 \mathrm{~g} / \mathrm{cm}^{3}$, the $h=1.54 \mathrm{~km}$, i.e., if the density over the slab remains the same as the surrounding, the backarc trough should be $1.54 \mathrm{~km}$ deep; if the density is lower, as one would expect from the upward curved isotherms (Toksöz and BIRD, 1977), then the trough would be shallower.

If isostatic readjustment is the mechanism for the formation of the interarc basin, then the isostatic anomaly over the interarc basin should approach zero and the width of the basin should be correlated with the presence of the slab underneath: the gentler the dip the wider the basin. The variation in width of the Lau-Havre Basin behind the Tonga-Kermadec arc can perhaps be explained this way. One could imagine that the adjustment would be more complete as the mantle material above the slab heats up and flows more readily.

\section{Conclusion}

By invoking the absolute motion of the plates, i.e. relative motion between the tectonic plates, and the more or less stationary mesosphere, we are able to explain the vertical profile of some of the Benioff zones. Although we are only making a qualitative correlation of the various factors involved, a numerical modelling of the situation is desirable. In fact, in order to deal with the details of the rather complex profiles of the different zones, one needs to do such modelling.

With regard to the interarc basins, we have proposed some additional mechanisms to explain their existence, recognizing that these mechanisms are probably neither universal nor complete. So far, the study of the interarc basins are limited to the use of magnetics, shallow seismic reflection method, heat flow and dredging. For further details of the deeper structures under the more interarc basins, seismic refraction profiles and/or reflection profiles are perhaps needed to yield additional critical data. edged.

The support of NSF Grant EAR76-14457 and INT76-20073 during the course of the work is acknowl-

\section{REFERENCES}

BARAZANGr, M. and B. IsAcks, Spatial distribution of earthquakes and subduction of the Nazca plate beneath South America, Geology, 4, 686-692, 1976.

Frank, F.G., Curvature of island arcs, Nature, 220, 363, 1968.

Engdahl, E. R. and C.H. Scholz, Double planed Benioff zone beneath island arcs: An unbending of the lithosphere, Abstr., p. 22., Int. Geodyn. Conf., Tokyo, 1978.

Green, D. and D.J. Cullen, The tectonic evolution of the Fiji region in The Western Pacific, edited by Coleman, pp. 127-145, Crane, Russak and Co., New York, 1973. 
Hasegawa, A., N. Umino, and A. TAkagi, Fine structure of deep seismic plane in northeast Japan, Abstr., Spring Meet. of Seismol. Soc. Jpn., 1976.

Hasegawa, A., N. Umino, and A. Takagr, Double-planed deep seismic zone beneath the northeastern Japan arc, Abstr., p. 44, Int. Geodyn. Conf., Tokyo, Japan, 1978.

Heiskanen, W.A., New isostatic tables for the reduction of the gravity values calculated on the basis of Airy's hypothesis, Publ. Isostatic Inst., No. 2, 1938.

Hess, H.H., Major structural features of the western north Pacific: An interpretation of H.O. 5485 Bathymetry chart, Korea to New Guinea, Geol. Soc. Am. Bull., 59, 417-446, 1946.

IsACKs, B., Focal mechanisms of earthquakes in western South America, EOS, Trans. Am. Geophys. Union, 51, $355,1970$.

IsACKs, B. and M. BARAZANGr, High frequency shear waves guided by a continuous lithosphere descending beneath western South America, Geophys. J. R. Astr. Soc., 33, 129-139, 1973.

IsACKs, B. and M. BARAzAngi, Geometry of Benioff zones: Lateral segments and downgoing bending of the subducted lithosphere, in Island Arcs, Deep Sea Trenches, and Back Arc Basin, Vol. 99, edited by Talwani and Pitman, p. 114, Am. Geophys. Union, 1977.

Isacks, B. and P. Molnar, Distribution of stresses in the descending lithosphere from a global survey of focalmechanism solutions of mantle earthquakes, Rev. Geophys. Space Phys., 9, 103-174, 1971.

JACOBy, W.R., Model experiment of plate movements, Nature (Phys. Sci.), 242, 130-134, 1973.

Kanamori, H. and K. ABE, Deep strucure of island arcs as revealed by surface waves, Bull. Earthq. Res. Inst., Tokyo Univ., 46, 1001-1025, 1968.

KARIG, D.E., Structural history of the Mariana arc system, Geol. Soc. Am. Bull., 83, 323-344, 1971 la.

KARIG, D.E., Origin and development of marginal basins, J. Geophys. Res., 76, 2542-2561, $1971 \mathrm{~b}$.

Katsumata, W. and L.R. Sykes, Seismicity and tectonics of Western Pacific: Izu-Mariana-Caroline and Ryukyu-Taiwan Regions, J. Geophys. Res., 74, 5923-5948, 1969.

LePichon, X., Sea-floor spreading and continental drift, J. Geophys. Res., 73, 3661-3697, 1968.

LuYendik, B., Dips of downgoing lithospheric plates beneath island arcs, Geol. Soc. Am. Bull., 81, 3411-3416, 1970.

McKenzie, D.P. and W.J. Morgan, Evolution of triple junctions, Nature, 224, 125-133, 1969.

Mrnear, J. and M.N. Toxsöz, Thermal regime of a downgoing slab and new global tectonics, J. Geophys. Res., 75, 1397-1419, 1970.

Minster, J.B., T.H. Jordan, P. Molnar, and E. Haines, Numerical modeling of instantaneous plate tectonics, Geophys. J.R. Astr. Soc., 36, 541-576, 1974.

Mizuno, A., Y. Okuda, S. Nagumo, H. Kagamr, and N. Nasu, Geology and subsidence history of the Daito ridge and associated basins, North Philippine Sea, Abstr. p. 102, Int. Geodyn. Conf., Tokyo, 1978.

Molnar, P. and J. Francheteau, The relative motion of 'hot spots' in the Atlantic and Indian Oceans during the Cenozoic, Geophys. J. Roy. Astron. Soc., 43, 763-774, 1975.

Morgan, W.J., Rises, trenches, grea.t faults and crustal blocks, J. Geoplyys. Res., 73, 1959-1981, 1968.

Morgan, W.J., Plate motions and deep mantle convection, Geol. Soc. Am. Bull., 132, 7-22, 1972.

Murauchi, S., N. Deu, S. Asano, T. Hotta, T. Yoshit, K. Asanuma, K. Hagiwara, T. Ichikawa, W.J. Sato, J.I. Ewing, N.T. Edgar, and R.E. Hontz, Crustal Structure of the Philippine Sea, J. Geophys. Res., 73, 3143-3171, 1968.

Poefrl, K.A., Inter-arc basins: A kinetic model, Geophys. Res. Lett., 5, 325-328, 1978.

SegawA, J. and Y. Tomoda, Gravity measurements near Japan and study of the upper mantle beneath the oceanic trench-marginal sea transition zone, in The Geophys. of the Pacific Ocean Basin and Its Margin, pp. 35-52, The Woolard Vol., Am. Geophys. Union, 1976.

Sclater, J.G., J.W. Hawkrns, J. Mammerickx, and G.G. Chase, Crustal extension between the Tonga and Lau ridges, Petrologic and geophysical evidence, Bull. Geol. Soc. Am., 83, 505-518, 1972.

SNoke, J.A., I.S. SACKs, and H. OKADA, A comparison of empirical model for explaining anomalous highfrequency arrivals from deep-focus South American earthquakes, EOS, Trans. Am. Geophys. Union, 54, $1140,1973$.

STAUdER, W., Mechanism and spatial distribution of Chilean earthquakes with relation to subduction of the oceanic plate, J. Geophys. Res., 74, 6696-6701, 1973.

Torsöz, M.N. and P. BIRD, Formation and evolution of marginal basins and continental plateaus, in Island Arcs, Deep Sea Trenches and Back Arc Basin, edited by Talwania and Pittma, pp. 1379-1394, Am. Geophys. Union, 1977.

Tovish, A. and G. Schumert, Island arc curvature, velocity of convergence and angle of subduction, Geophys. Res. Lett., 5, 329-332, 1978.

Tullrs, T.E., Evidence that lithospheric plates act as anchors (abstr.), EOS, Trans. Am. Geophys. Union, 53, $522,1972$. 
TULIIs, T.E., Factors determining the dip of downgoing slabs, preprint, 1976.

Uyeda, S., Some basic problems in the trench-back arc system, in Island Arco, Deep Sea Trenches, and Back Arc Basins, edited by Talwani and Pittman, pp. 1-14, Am. Geophys. Union, 1977.

UYEDA, S. and H. KANAMORI, Back-arc opening and the mode of subduction, J. Geophys. Res., 1978 (in press).

Vogt, P.R., A. Lowrie, D.R. Bracey, and R.N. Hey, Subduction of aseismic oceanic ridges: Effects on shape, seismicity and other characteristics of consuming plate boundaries, Geol. Soc. Am. Spec. Paper $172,1976$.

Weissel, J.K., Evolution of the Lau basin by the growth of small plates, in Island Arcs, Deep Sea Trenches, and Back Arc Basins, edited by Talwani and Pittman, pp. 429-436, Am. Geophys. Union, 1977.

Wirson, J.T., Mantle plunes and plate motions, Tectonophysics, 19, 149-164, 1973.

Wilson, J.T., J.A. Jacobs, R.D. Russel, and J.T. Wilson, Physics and Geology, Chap. 17, McGraw-Hill, New York, 1974.

Wu, F.T., Structural history of the Mariana Island Arc System: Discussion, Geol. Soc. Am. Bull., 82, 26712672, 1971.

Wu, F.T., The Philippine Sea Plate: "A sinking towel", Tectonophysics, 14, 81-86, 1972. 